\title{
THE ROLE OF CRITICAL THINKING AND EXECUTIVE FUNCTION IN MISCONCEPTIONS IN PSYCHOLOGY
}

\author{
Heru Astikasari Setya Murti ${ }^{1,2}$, Thomas Dicky Hastjarjo ${ }^{2}$, Bhina Patria ${ }^{2}$ \\ ${ }^{1}$ Faculty of Psychology, Universitas Kristen Satya Wacana \\ J1. Diponegoro 52 - 60, Salatiga, Jawa Tengah, Indonesia \\ ${ }^{2}$ Faculty of Psychology, Universitas Gadjah Mada \\ J1. Sosio Humaniora Bulaksumur, Karang Malang, Caturtunggal, Kec. Depok, \\ Kabupaten Sleman, Daerah Istimewa Yogyakarta, Indonesia, 55281
}

heru.astika@gmail.com

\begin{abstract}
Misconception in psychology is a belief that is broadly contradicting to scientific evidence and is particularly common in the field of psychology. It is important to study misconceptions in psychology considering the contribution of the effort to provide education or to demonstrate rejection of fallacies of popular ideas/themes. Misconceptions in psychology relates to critical thinking as well as the executive function (EF) that controls and regulates cognitive processes. This research aims to determine the role of critical thinking and EF (cognitive flexibility, working memory, and inhibitory control) with misconceptions in psychology. This study used nonexperimental methods, using test (paper and pencil) and PEBL/ Psychology Experiment Building Language (computerized). The sampling technique used was convenience sampling. The subjects in this study were 153 psychology students, consisting of 105 students from Universitas Gadjah Mada (UGM) and 48 students from Universitas Negeri Yogyakarta (UNY). Instruments that were used for data collection were the misconception in psychology test, critical thinking test, Wisconsin/Berg Card Sorting Test (WCST/BCST), Backward Digit Span, and Stroop Test. There is no correlation between cognitive flexibility and misconceptions in psychology, so cognitive flexibility is not included in the calculation of hierarchical regression analysis. Based on the results of hierarchical regression analysis, it can be concluded that the role of inhibitory control on psychological misconceptions is $11.4 \%, \Delta R^{2}=.114 ; b^{*}=.33 ; t(149)=4.52, p<.001$; the role of working memory is $3 \%, \Delta R^{2}=$ $.030 ; b^{*}=-.16 ; t(149)=-2.19, p=.03$; and the role of critical thinking is $2.6 \%, \Delta R^{2}=.026 ; b^{*}=-.19 ; t(149)=-$ $2.53, p=.01$.
\end{abstract}

Keywords: misconception in psychology; critical thinking; executive function; working memory; inhibitory control.

\section{INTRODUCTION}

Psychology as a scientific study of behavior and mental processes cannot be separated from daily human life. Virtually every day, the news media, television shows, films and internet bombard the public with claims regarding a host of psychological topics, such as brain function, psychic symptoms, out of body experience, memory recovery, polygraph testing, romantic relationships, parenting, child sexual abuse, mental disorders, crime, and psychotherapy (Furnham \& Grover, 2019; Lilienfeld et al., 2010; Zajac et al., 2013). However, it turns out that not all information provided by the media is correct. Information is repeated, becomes 'fact' and leads to incorrect assumptions, because it appears logical and reasonable
(Furnham \& Hughes, 2014; Lewandowsky et al., 2012). This condition causes the circulation of large amounts of inaccurate information and leads to the spread of misconceptions in psychology. Individuals also tend to continue to rely on familiar and more accessible misinformation, making misconceptions difficult to erase (Hughes et al., 2012; Vosniadou, 2019).

Misconceptions are a belief that generally contradict scientific evidence, and are particularly common in psychology (Gardner \& Brown, 2013). Gardner and Brown (2013) referred to the error as misconception in psychology. There is no single specific term for false conception of psychology. Books of psychology use several terms, namely psychological misconception (Bensley \& 
Lilienfeld, 2015), misconception in psychology (Gardner \& Brown, 2013) and misconception about psychology (Hughes et al., 2013). Furthermore, this research will use the term of misconception in psychology. Taylor and Kowalski (2014) define misconceptions in psychology as inaccurate based on outdated concepts, while Bensley and Lilienfeld (2015) define misconceptions in psychology as mistaken rational beliefs inconsistent with the consensus of highquality research in psychology. Although the source of misconceptions is often unknown, they feel familiar, intuitively correct, and consistent with what 'everyone knows'.

Lilienfeld et al. (2010) say that psychology often requires that people who study it should not trust common sense and set aside intuition. However, it is undeniable that in a world where information is quickly and easily accessible, misinformation about psychology is immediately accepted as fact. Without a dependable guide, this situation is at risk of becoming lost in a jungle of misconceptions (Lilienfeld et al., 2010), moreover, the basic terms of psychology itself cannot necessarily be explained correctly by psychology students (Rahayu et al., 2012). Lewandowsky et al. (2012) point out that misconceptions in psychology often come from information obtained based on unsubstantiated, nonscientific sources, including everyday conversations, media, fiction, and rumor. In other words, misconceptions in psychology are a common-sense belief because it generally comes from informal sources and is usually recognized as 'true'. A surprising fact about undergraduate education in psychology is that not only do students attend lectures with various misconceptions in psychology (Gardner \& Brown, 2013), but they also finish college while holding these inaccurate beliefs (Lyddy \& Hughes, 2012; Taylor \& Kowalski, 2014). One of the reasons that remains unexplored as to why misconceptions in psychology are so prevalent and persistent is that students may not know that their knowledge is incorrect (Bensley et al., 2015; Lyddy \& Hughes, 2012). Therefore, given the work that needs to be made in an effort to provide better education or show a rejection of erroneous but popular ideas/themes, research on misconceptions in psychology is very important (Bensley et al., 2014).

Misconceptions in psychology are often associated with critical thinking. Bensley et al. (2014) attribute these misconceptions to a lack of critical thinking skills and Lilienfeld et al. (2010) say that the most important thing to deal with misconceptions in psychology is the use of critical thinking, which are required for evaluating psychological claims in everyday life. The susceptibility towards accepting misconceptions is associated with weakness in the critical thinking skills of students (Gardner \& Brown, 2013; Taylor \& Kowalski, 2012). Critical thinking skills are very important to students, a lack of critical thinking skills among students makes them vulnerable to misconception in psychology (Gardner \& Brown, 2013; Taylor \& Kowalski, 2012). Students are expected to acquire critical thinking skills during their college years, because the challenges they will encounter after graduating are greater (Sari \& Hastjarjo, 2009; Winenggar \& Hastjarjo, 2015). However, critical thinking among students needs to be improved (Satwika et al., 2018) and research also shows that more work is needed in developing students critical thinking skills (Uribe-Enciso et al., 2017).

The formulation of critical thinking can vary, but there are at least two different considerations of conceptualization of critical thinking (a) considering critical thinking as discipline-specific or discipline-general and (b) considering critical thinking as a set of skills or as a combination of skills with a disposition towards being a "critical thinker" (Verburgh et al., 2013). Halpern (2014) defines critical thinking as the use of the cognitive skills and strategies that increase the probability of desired outcomes. In this case, critical thinking described as purposeful, reasoned and goal-directed, thinking to solve problems, draw conclusions, calculate opportunities, and make decisions. Critical thinking is also said to be a skill to make 
assessments through interpretation, analysis, evaluation and drawing conclusions (Fong et al., 2017). With critical thinking, a person will determine carefully and consciously whether to accept, reject, or suspend judgment about a claim, and can confidently accept or reject it (Moore \& Parker, 2014). Mayer and Goodchild (1990) state that critical thinking is the ability to understand and evaluate arguments. The ability to understand arguments consists of three stages, (1) understanding statements, (2) understanding empirical evidence, (3) understanding theoretical explanations, while the ability to evaluate consists of (1) evaluating statements, (2) evaluating empirical evidence, evaluating theoretical explanations.

Research conducted by Bensley et al. (2014) shows that when using critical thinking skills, students can change misconceptions in psychology that they previously believed. The "critical" part of critical thinking shows an evaluation component that can be a constructive reflection of both positive and negative attributes. When a person thinks critically, they evaluate the results of the thought process, or it can be said that misconceptions occur due to a lack of critical thinking skills (Halpern, 2014). Thus, critical thinking can be a way to help reduce misconceptions in psychology. Seeing how important critical thinking is, there needs to be serious handling of fostering students' critical thinking (Puspyanto \& Hastjarjo, 2015). One aspect of critical thinking, which is the ability to evaluate arguments, is considered to be able to improve the critical thinking of students (Sari \& Hastjarjo, 2009).

In addition to critical thinking, another factor that needs to be observed is the role of executive function (EF) which controls and regulates cognitive processes and is important for the acquisition of conceptual knowledge (Bascandziev et al., 2016; Doebel, 2020). EF is a cognitive system that controls and regulates other cognitive processes, including flexibility in thinking, planning, inhibition and coordination as well as integration of information (Baddeley, 1996). Best (2012) argues that $\mathrm{EF}$ is a set of cognitive processes used to attempt, control and direct thoughts and behavior to achieve goals. This theory is in line with Homer et al. (2018) that EF is a necessary skill set in planning, monitoring and controlling the cognitive processes. Similarly, Diamond (2013) states that EF is a set of capabilities that include controlling and flexibly manipulating thinking in mental processes, maintaining specific goals, inhibiting different types of disorders both endogenous and exogenous, and choosing the right responses. EF, also called executive control or cognitive control, refer to top-down mental processes needed when a person has to concentrate and pay attention, when going on automatic or relying on instinct or intuition would be ill-advised, insufficient or impossible. According to Diamond (2013) there is general agreement that there are three core EFs namely inhibitory control, working memory, and cognitive flexibility. Inhibitory control plays a role in controlling one's attention, behavior, thoughts, and/or emotions to override a strong internal predisposition or external lure. Working memory plays a role in holding information in mind and mentally working with it (e.g., connecting one thing to another or using information to solve problems), cognitive flexibility plays a role in changing perspective or approaching a problem, being flexible enough to adjust to changed demands or priorities (e.g., switching from one task to another).

Based on these explanations, this research aims to determine the role of critical thinking and EF with misconception in psychology. The hypothesis of research is that there is a negative role of critical thinking and EF in misconception in psychology. Students' high critical thinking and EF can result in low misconceptions in psychology on the other hand students' low critical thinking and EF can result in high misconceptions in psychology.

\section{METHOD}

The methods used in this research are nonexperimental, by providing assessments using 
tests (paper and pencil) and PEBL/Psychology Experiment Building Language (computerized). The independent variables used in this research were critical thinking and EF (including components of cognitive flexibility, working memory, and inhibitory control), while dependent variables used were misconceptions in psychology. The sampling technique used was convenience sampling. The subjects of the research were 153 psychology students, consisting of 105 students from Universitas Gadjah Mada (UGM) and 48 students from Universitas Negeri Yogyakarta (UNY), class of 2018 and 2019. The data collection tools used were Misconception in Psychology Test, Critical thinking Test, Wisconsin/Berg Card Sorting Test (WCST/BCST), Backward Digit Span, and Stroop Test.

Misconceptions in Psychology Test (Gardner \& Brown, 2013) which was translated into Indonesian, was adopted to assess misconceptions in psychology. Forward translation was done by psychology academics, graduate, and postgraduates from universities abroad, while backward translation was done by an English Language Institute. The test consisted of 41 items, covering 11 areas of brain and behavior (e.g., "Most people use only about $10 \%$ of their brain power") development and aging (e.g., "A small percentage of the elderly live in nursing homes"), memory (e.g., "It is not common for individuals to repress the memories of traumatic experiences"), intelligence and learning (e.g., "Negative reinforcement is a type of punishment"), consciousness (e.g., "Hearing material while we are asleep (sleep learning) can be an effective aid to learning"), emotion and motivation (e.g., "Women are no better than men at accurately guessing the feelings of others"), social psychology (e.g., "We are most romantically attracted to people who are similar to us", personality (e.g., "We cannot tell a person's personality by merely looking at their handwriting"), mental illness (e.g., "People with schizophrenia do not have multiple personalities"), psychology and law (e.g., "The rates of serial killers are no higher among Whites than other racial groups"), and psychological treatment (e.g., "Taking a placebo (i.e. sugar pill) can change brain functioning and chemistry"). Misconceptions in psychology Test scores explain that score 1 = completely false, score $2=$ mostly false, score 3 = partly false and partly true, score 4 $=$ mostly true, score $5=$ completely true, and score $6=$ do not know. The high total score on this test indicates high misconception, while a low total score indicates low conception. The reliability of this test is $\alpha=.84$.

The Critical Thinking assessment was performed using the Critical Thinking Test from Mayer and Goodchild (1990) which was translated by previous researchers (Sari \& Hastjarjo, 2009). This test consists of 32 questions (e.g., "Can I state the assertion (and underline the key terms)?"). Referring to Sari and Hastjarjo's research (2009), two questions were void, so only 30 questions were applied in this research. Scoring procedure (ratings) given by more than 1 rater is expected to minimize the influence of subjectivity. The processed data obtained from 3 raters, the estimated reliability .96 $(p<$ $.001)$ and average reliability rating of three raters $.98(p<.001)$. The high rating reliability coefficient of the 2 ways of computing means that the rating that has been given by each rater is consistent with each other. Critical thinking scores have a positive meaning, which means that a high score indicates high critical thinking.

EF assessment was performed by measuring its components which are cognitive flexibility measured using PEBL Berg Card Sorting Test-64 (BCST-64), which is an adaptation of Wisconsin Card Sort-64 or short form of Wisconsin Card-Sorting Test (Mueller \& Piper, 2014). This version uses 24 decks of cards and participants will perform 64 matching tasks. In this test individuals are presented with 24 stimulus cards. The cards differ in number, color, and design. The task of each individual is to pair the additional cards to a number, color or design. Individuals 
are then presented with stacks of cards in a specific order and asked to match each card with one of the stimulus cards. However, the individual is never told which attributes of the card should match. They are only notified whether the match is right or wrong. During testing, the rule of the game is changed. The time needed for an individual to learn a new rule is measured as well as the number of mistakes they make at that time. The time they need to adjust and the number of mistakes made when the rules are changed are used to determine the level of cognitive function of the individual. Scores on cognitive flexibility have a negative meaning which indicates that if an individual obtains a higher score, they have lower cognitive flexibility skills.

Working memory assessment was performed using Digit span Backward and PEBL (Brydges et al., 2015). Digit span Backward is delivered as written in the WAIS-III manual. The subject is presented with a series of numbers (at a speed of one digit per second), and then the subject is required to repeat them in the opposite order. Tests are halted when the subject makes a mistake twice in a row or when the number sequences (8 sets) are completed (Lefebvre et al., 2005). Working memory scores have a positive meaning, a high score indicates high working memory skills.

Inhibitory control assessment was performed using Stroop test and PEBL (Park \& Etnier, 2019). Stroop Test consists of three tasks, each lasting 45 seconds: (1) Word tasks: Reading the name of colors printed in black ink; (2) Color tasks: Naming colors of meaningless semantic symbols (XXXX) printed in colored ink (e.g., red, blue or green); and (3) Color-Word tasks: Reading the names of colors printed in colored ink so that the words and ink colors don't match (for example, the word blue is printed in red ink and the correct response is "Red"). Each task generates a score (color, word, and colorword), based on the numbers of completed items (Faraone et al., 2005). The reliability coefficient of overall test-retest Stroop task is
.67 (Franzen et al., 1987). Scores on inhibitory control have a negative meaning which indicates that if an individual obtains a higher score, they have lower inhibitory control skills. The procedure for assessing the three components of EF refers to Ardi and Wimbarti research (2018).

Misconception in Psychology and Critical Thinking Tests were presented to subjects using the paper and pencil method and carried out in a classroom, while EF assessment was performed in a computer laboratory where the PEBL program was already installed in the computers with battery test BCST, Working Memory and Stroop Test. Subjects' participation is voluntary and students' agreement to participate is declared in informed consent. Analysis of this research data was using hierarchical regression analysis techniques with the help of SPSS.

\section{RESULT AND DISCUSSION}

\section{Table 1.}

Description of Hypothetical and Empirical Score Data

\begin{tabular}{clcc}
\hline Variable & & Hypothetical & Empirical \\
\hline \multirow{4}{*}{ Misconception } & Max & 41 & 63 \\
in Psychology & $M$ & 123 & 150 \\
& SD & 27.3 & 105.25 \\
\hline \multirow{4}{*}{ Critical } & Min & 0 & 18.27 \\
Thinking & Max & 30 & 22 \\
& SD & 15 & 10.72 \\
& Min & 0 & 3.94 \\
\hline \multirow{3}{*}{ Cognitive } & Max & 64 & 36 \\
Flexibility & M & 32 & 93.59 \\
& SD & 5.33 & 14.87 \\
\hline \multirow{4}{*}{ Working } & Min & 0 & 0 \\
Memory & Max & 9 & 14 \\
& M & 5.5 & 6.58 \\
& SD & 1.17 & 2.55 \\
\hline \multirow{2}{*}{ Inhibitory } & Min & 2 & 45.43 \\
Control & Max & 500 & 391.22 \\
& SD & 251 & 146.93 \\
& 83 & 64.15 \\
\hline
\end{tabular}

Based on Table 1 we find that the empirical average of critical thinking is lower than the hypothetical average, which means that the 
average of critical thinking skills of the subjects is lower than the hypothetical average. The empirical average of cognitive flexibility is higher than the hypothetical average, which means that the average cognitive flexibility skills of the subjects is lower than the hypothetical average. The empirical average of the working memory is higher than hypothetical, which means that the average of working memory skills of the subjects is higher than the hypothetical average. The empirical average of inhibitory control is lower than the hypothetical average, which means that the average of inhibitory control skills of the subjects is higher than the hypothetical average.

Meanwhile, from the calculation of bicorrelation between variables, we find that there is a negative correlation between misconception in psychology and critical thinking $(r=-.16, p=.02)$, there is a negative correlation between misconception in psychology and working memory $(r=-.16, p$ $=.02$ ), and there is a positive correlation between misconception in psychology and inhibitory control $(r=-.33, p<.001)$, while in misconception in psychology with cognitive flexibility there is a correlation but it is not statistically significant $(r=-.11, p=.44)$.

The negative correlation between misconceptions in psychology and critical thinking means that the higher the misconception in psychology equals the lower in critical thinking and vice versa. The negative correlation between misconception in psychology and working memory means that the higher misconception in psychology equals the lower working memory, and vice versa. Since inhibitory control has a negative value, then the positive correlation between misconception in psychology and inhibitory control means that a higher misconception in psychology equals the lower inhibitory control, and vice versa. Because cognitive flexibility has a correlation with misconception in psychology but is insignificant statistically, cognitive flexibility is not included in the calculation of hierarchical regression analysis. More is displayed in Table 2.

\section{Table 2.}

Correlation Between Variables

\begin{tabular}{cccccc}
\hline & MP & CT & CF & WM & IC \\
\hline MP & - & - & - & - & - \\
CT & $-.161^{*}$ & - & - & - & - \\
CF & -.011 & -.030 & - & - & - \\
WM & $-.167^{*}$ & -.035 & .123 & - & - \\
IC & $.330^{* *}$ & .069 & -.055 & -.029 & - \\
\hline
\end{tabular}

Note. $\mathrm{MP}=$ Misconception in Psychology; CT $=$ Critical Thinking; $\mathrm{CF}=$ Cognitive Flexibility; $\mathrm{WM}=$ Working Memory; IC = Inhibitory Control.

${ }^{*} p<.05 .{ }^{* *} p<.001$.

Table 3.

Hierarchical Regression

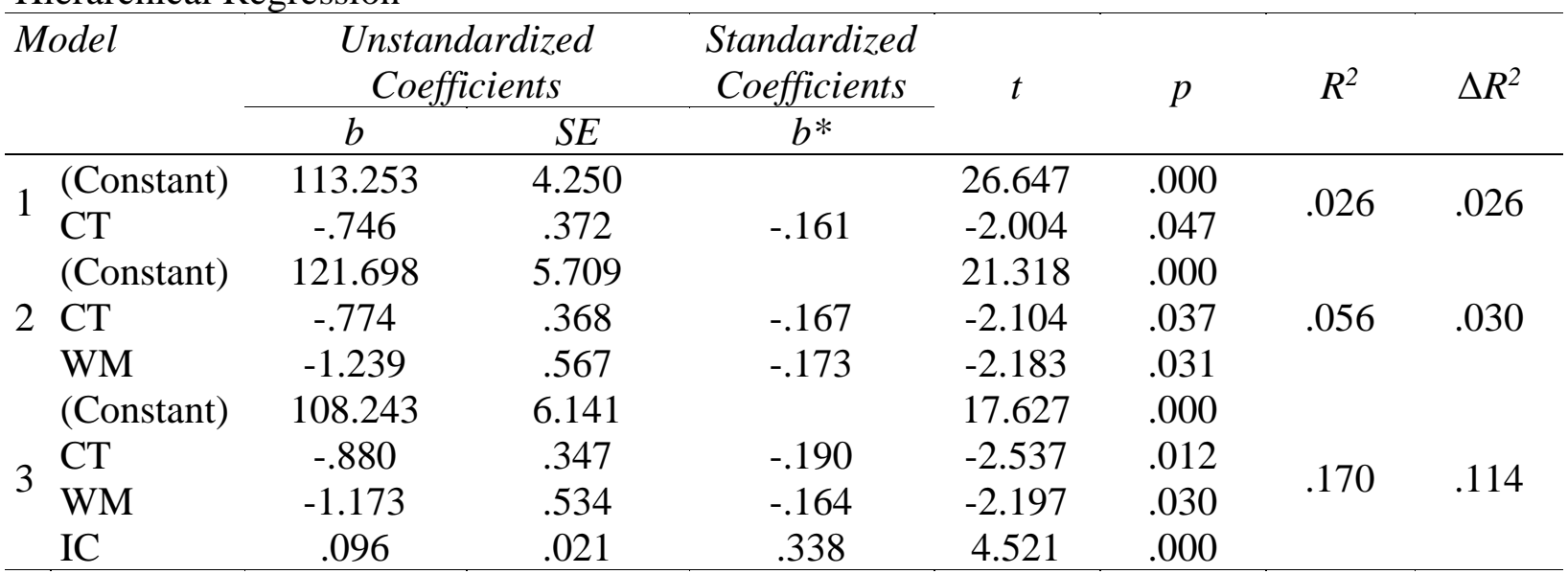

Note. Misconception in psychology as the dependent variable. $\mathrm{CT}=$ Critical Thinking; $\mathrm{WM}=$ Working Memory; IC = Inhibitory Control. 
Based on the results of hierarchical regression analysis of critical thinking, working memory, and inhibitory control toward misconception in psychology, it can be concluded that inhibitory control plays a role misconception in psychology as large as $11.4 \%, \Delta R^{2}=.114$; $b^{*}=.33 ; t(149)=4.52, p<.001$; working memory plays a role in misconception in psychology as large as $3 \%, \Delta R^{2}=.030 ; b^{*}=-$ $.16 ; t(149)=-2.19, p=.03$; and critical thinking plays a role in misconception in psychology as large as $2.6 \%, \Delta R^{2}=.026 ; b^{*}=$ $-.19 ; t(149)=-2.53, p=.01$. The results of hierarchical regression analysis can be seen in table 3 .

Thus, it can be concluded that critical thinking, working memory and inhibitory control can work as predictors of misconception in psychology. From the regression analysis that has been performed, a model of regression equation can be made $\mathrm{Y}$ $=108.243+.338 \mathrm{X}_{1}-.164 \mathrm{X}_{2}-.19 \mathrm{X}_{3}$, with $\mathrm{Y}$ is a misconception in psychology, $X_{1}$ is inhibitory control, $\mathrm{X}_{2}$ is working memory, and $\mathrm{X}_{3}$ is critical thinking.

The EF component inhibitory control contributes the most, compared to working memory and critical thinking. This finding is in line with previous findings that inhibitory control plays an important role in "misconceptual" issues (Babai et al., 2012; Shtulman \& Valcarel, 2012). Inhibitory control is recognized to act as a mechanism used to suppress misconceptions by blocking the dominant but improper response (Mason et al., 2019), helping to reduce or eliminate incorrect concept interference, and facilitating the use of appropriate concepts (Butterfuss \& Kendeou, 2020). The results show that inhibitory control positively contributed to misconception in psychology, or it can be said that high scores on inhibitory control (or low inhibitory control skills) are associated with the students' high scores in misconception in psychology, and vice versa. Inhibition is a key concept in psychology because so much of behavioral success depends on inhibition. One needs to impede irrelevant information or clues to focus and retrieve certain memories, as well as to inhibit automatic responses with the aim of making adaptive choices (Foisy et al., 2015). Diamond (2013) says that inhibitory control enables a person to concentrate more and regulate cognitive function. Low performance in inhibitory control will cause a person to be less able to regulate non-relevant information and lead to misleading perceptions (Brookman-Byrne et al., 2018). Thus, when inhibitory control is low (the score on inhibitory control assessment is high), a person will experience difficulties to determine the right information because they are disturbed by irrelevant and uncontrolled information, so the chances of misconception in psychology are higher.

For the EF component working memory, the calculation results show that working memory negatively contributed to misconception in psychology, or it can be said that low scores in working memory causes high misconception in psychology among students, and vice versa. Working memory relates to the ability to retain and process information (Brehmer et al., 2012; Cowan, 2014), so it is understandable that information obtained by a person may have an impact on acceptance of misconception in psychology. When a student has a valuable working memory, they will be able to determine the right information according to the receipt of the processed information, and vice versa.

This research also corroborates previous research that cited misconception in psychology as a failure to think critically (Bensley \& Lilienfeld, 2017) and supports the conclusion that critical thinking is needed to deal with misconception (Dellantonio \& Pastore, 2020). Critical thinking is crucial because it enables one to evaluate psychological claims better in everyday life. Based on the calculation result, critical thinking negatively contributes to misconception in psychology, or low critical thinking skills can cause high misconception in psychology students, and vice versa. When a student is poor at critical thinking, they will 
be vulnerable to misconceptions in psychology because they are unable to evaluate psychological claims (Wilson, 2018).

Meanwhile, the results of this research show that cognitive flexibility does not contribute to misconception in psychology. This is explained through the function of cognitive flexibility itself, cognitive flexibility serves to help a person to make adjustments easily when facing difficulties or encountering new information (Roebers, 2017), in other words, cognitive flexibility is related to the function of adaptation to a particular condition. Cognitive flexibility plays a role in changing a perspective or approach to a problem, being flexible in adjusting to new rules or priorities, such as switching from one task to another, or one concept to another (Diamond, 2013). Therefore, if there is no new information that opposes or corrects a misconception in psychology, which indicates the need for adaptation function, cognitive flexibility plays no role at all in misconception in psychology.

\section{CONCLUSION}

Based on the analysis results that have been accomplished, we can conclude that critical thinking, working memory and inhibitory control can be predictors of misconception in psychology, while cognitive flexibility does not predict misconception in psychology. The negative correlation between critical thinking and misconception suggests that the higher critical thinking the lower misconception in psychology and vice versa. The negative correlation between working memory and misconception in psychology suggests that the higher working memory the lower misconception in psychology and vice versa. Considering inhibitory control has a negative meaning, then a positive correlation between inhibitory control and misconception indicates that the higher inhibitory control the lower misconception in psychology and vice versa. In predicting misconception in psychology inhibitory control plays a role of $11.4 \%$, working memory by $3 \%$, and critical thinking by $2.6 \%$.

\section{ACKNOWLEDGEMENT}

This research is an issued through the Research Grant of the Faculty of Psychology of UGM Fiscal Year 2019/2020. Thanks to Faculty of Psychology of UGM who provided funding for this research through the Research Grant of the Faculty of Psychology of UGM Fiscal Year 2019/2020.

\section{REFERENCES}

Ardi, S. F., \& Wimbarti, S. (2018). Hubungan antara kemampuan executive function dengan kecenderungan perilaku menyontek yang dimediatori oleh performansi akademik pada siswa Sekolah Menengah Pertama [Unpublished master's thesis]. Faculty of Psychology, Universitas Gadjah Mada.

Babai, R., Eidelman, R. R, \& Stavy, R. (2012). Pre-activation of inhibitory control mechanisms hinders intuitive reasoning. International Journal of Science and Mathematics Education, 10(2012), 763-775. doi: 10.1007/s10763011-9287-y

Baddeley, A. (1996). Exploring the central executive. The Quarterly Journal of Experimental Psychology A: Human Experimental Psychology, 49A(1), 5-28. http://dx.doi.org/10.1080/713755608

Bascandziev, I., Powell, L. J., Harris, P. L., \& Carey, S. (2016). Cognitive development: A role for executive functions in explanatory understanding of the physical world. Cognitive Development, 39(2016), 71-85.

https://doi.org/10.1016/j.cogdev.2016.04. 001

Bensley, D. A., \& Lilienfeld, S. O. (2015). What is a psychological misconception? Moving toward an empirical answer. Teaching of Psychology, 42(4), 282-292. https://doi.org/10.1177/00986283156030 59 
Bensley, D. A., \& Lilienfeld, S. O. (2017). Psychological misconceptions: Recent scientific advances and resolved issues. Current Directions in Psychological Sciences, 26(4), 377-382. https://doi.org/10.1177/09637214176990 26

Bensley, D A., Lilienfeld, S. O., \& Powell, L. A. (2014). A new measure of psychological misconceptions: Relations with academic background, critical thinking, and acceptance of paranormal and pseudoscientific claims. Learning and Individual Differences, 36(2014), 9-18. http://dx.doi.org/10.1016/j.lindif.2014.07. 009

Bensley, D. A., Rainey, C., Lilienfeld, S. O., \& Kuehne, S. (2015). What do psychology students know about what they know in psychology? Scholarship of Teaching and Learning in Psychology, 1(4), 283-297. http://dx.doi.org/10.1037/st10000035

Best, J. (2012). Exergaming immediately enhances children's executive function. Developmental Psychology, 48(5), 15011510. https://doi.org/10.1037/a0026648

Brehmer, Y., Westerberg, H., \& Bäckman, L. (2012). Working-memory training in younger and older adults: Training gains, transfer, and maintenance. Frontiers in Human Neuroscience, 6(63), 1-7. https://doi.org/10.3389/fnhum.2012.0006 3

Brookman-Byrne, A., Mareschal, D., Tolmie, A. K., \& Dumontheil, I. (2018). Inhibitory control and counterintuitive science and maths reasoning in adolescence. PLoS One, 13(6), 1-19. https://doi.org/10.1371/journal.pone.0198 973

Brydges, C. R., Ozolnieks, K. L., \& Roberts, G. (2017). Working memory-not processing speed-mediates fluid intelligence deficits associated with attention deficit/hyperactivity disorder symptoms. Journal

of

Neuropsychology, 11(3), 362-377. https://doi.org/10.1111/jnp.12096

Butterfuss, R., \& Kendeou, P. (2020). Reducing interference from misconceptions: The role of inhibition in knowledge revision. Journal of Educational Psychology, 112(4), 782794. http://dx.doi.org/10.1037/edu0000385

Cowan, N. (2014). Working memory underpins cognitive development, learning, and education. Educational Psychology Review, 26(2), 197-223. https://doi.org/10.1007/s10648-0139246-y

Dellantonio, S., \& Pastore, L. (2020). Ignorance, misconceptions and critical thinking. Synthese, 1-29. https://doi.org/10.1007/s11229-01902529-7

Diamond, A. (2013). Executive functions. Annual Review Psychology, 64, 135-68. https://doi.org/10.1146/annurev-psych113011-143750

Doebel, S. (2020). Rethinking executive function and its development. Perspectives on Psychological Science, 15(4), 942-956. https://doi.org/10.1177/17456916209047 71

Faraone, S. V., Biederman, J., Spencer, T., Michelson, D., Adler, L., Reimherr, F., \& Seidman, L. (2005). Atomoxetine and Stroop Task performance in adult attention-deficit/hyperactivity disorder. Journal of Child \& Adolescent Psychopharmacology, 15(4), 664-670. https://doi.org/10.1089/cap.2005.15.664

Foisy, L. M. B., Potvin, P., Riopel, M., \& Masson, S. (2015). Is inhibition involved in overcoming a common physics misconception in mechanics? Trends in Neuroscience and Education, 4(1-2), 26- 
36.

http://dx.doi.org/10.1016/j.tine.2015.03.0 01

Fong, C. J., Kim, Y., Davis, C. W., Hoang, T., \& Kim, Y. W. (2017). A meta-analysis on critical thinking and community college student achievement. Thinking Skills and Creativity, 26(2017), 71-83. http://dx.doi.org/10.1016/j.tsc.2017.06.00 2

Franzen, M. D., Tishelman, A. C., Sharp, B. H., \& Friedman, A. C. (1987). An investigation of the test-retest reliability of the Stroop Color-Word Test across two intervals. Archives of Clinical Neuropsychology, 2(3), 265-272. https://doi.org/10.1016/08876177(87)90014-X

Furnham, A., \& Grover, S. (2019). Myths and misconceptions about the psychology of adolescence and intimate relationships. Psychology, 10(15), 2166 2176. https://doi.org/10.4236/psych.2019.10151 37

Furnham, A., \& Hughes, D. J. (2014). Myths and misconceptions in popular psychology: Comparing psychology students and the general public. Teaching of Psychology, 41(3), 256-261. https://doi.org/10.1177/00986283145379 84

Gardner, R. M., \& Brown, D. L. (2013). A test of contemporary misconceptions in psychology. Learning and Individual Differences, 24(2013), 211-215. https://doi.org/10.1016/j.lindif.2012.12.0 08

Halpern, D. F. (2014). Thought and knowledge (5th ed.). Taylor \& Francis.

Homer, B. D., Plass, J. L., Raffaele, C., Ober, T. M., \& Ali, A. (2018). Improving high school students' executive functions through digital game play. Computers \&
Education, 117(2018), 50-58. https://doi.org/10.1016/j.compedu.2017.0 9.011 .

Hughes, S., Lyddy, F., \& Kaplan, R. (2012). The impact of language and response format on student endorsement of psychological misconceptions. Teaching of Psychology, 40(1), 31-37. https://doi.org/10.1177/00986283124658 61

Hughes, S., Lyddy, F., \& Lambe, S. (2013). Misconceptions about psychological science: A review. Psychology Learning \& Teaching, 12(1), 20-31. http://dx.doi.org/10.2304/plat.2013.12.1. 20

Lefebvre, C. D., Marchand, Y., Eskes, G. A., \& Connolly, J. F. (2005). Assessment of working memory abilities using an eventrelated brain potential (ERP)-compatible digit span backward task. Clinical Neurophysiology, 116(7), 1665-1680. https://doi.org/10.1016/j.clinph.2005.03.0 15

Lewandowsky, S., Ecker, U. K. H., Seifert, C. M., Schwarz, N., \& Cook, J. (2012). Misinformation and its correction: Continued influence and successful debiasing. Psychological Science in the Public Interest, 13(3), 106-131. https://doi.org/10.1177/15291006124510 18

Lilienfeld, S., O., Lynn, S. J., Ruscio, J., \& Beyerstein, B. L. (2010). 50 Great myths of popular psychology. Wiley-Blackwell.

Lyddy, F., \& Hughes, S. (2012). Attitudes towards psychology as a science and the persistence of psychological misconceptions in psychology undergraduates. In V. Karandashev \& S. McCarthy (Eds.), Teaching psychology around the world (Vol. 3, pp. 330-349). Cambridge Scholars Publishing.

Mason, L., Zaccoletti, S., Carretti, B., Scrimin, S., \& Diakidoy, I. A. N. (2019). 
The role of inhibition in conceptual learning from refutation and standard expository texts. International Journal of Science and Mathematics Education, 17(3), 483-501. https://doi.org/10.1007/s10763-0179874-7

Mayer, R. E., \& Goodchild, F. (1990). The critical thinker. Wm. C. Brown.

Moore, B.N., \& Parker, R. (2014). Critical thinking. McGraw Hill Higher Education.

Mueller, S. T., \& Piper, B. J. (2014). The Psychology Experiment Building Language (PEBL) and PEBL Test Battery. Journal of Neuroscience Methods, 222(2014), 250-259. http://dx.doi.org/10.1016/j.jneumeth.201 3.10 .024

Park, S., \& Etnier, J. L. (2019). Beneficial effects of acute exercise on executive function in adolescents. Journal of Physical Activity and Health, 16(6), 423429. https://doi:10.1123/jpah.2018-0219

Puspyanto, A., \& Hastjarjo, T. D. (2015). Hubungan antara efikasi diri dan critical thinking pada siswa [Unpublished undergraduate's thesis]. Faculty of Psychology, Universitas Gadjah Mada.

Rahayu, R. W., Emeldah, \& Hastjarjo, T. D. (2012). Konsep inti psikologi menurut dosen pengampu mata kuliah psikologi umum [Unpublished manuscript]. Faculty of Psychology, Universitas Gadjah Mada.

Roebers, C. M. (2017). Executive function and metacognition: Towards a unifying framework of cognitive selfregulation. Developmental

Review, 45(2017), 31-51. https://doi.org/ 10.1016/j.dr.2017.04.001

Sari, A. M., \& Hastjarjo, T. D. (2009). Perbedaan kemampuan mengevaluasi argumen antara mahasiswa S1 dan S2
[Unpublished master's thesis]. Faculty of Psychology, Universitas Gadjah Mada.

Satwika, Y.W., Laksmiwati, H., \& Khoirunnisa, R.N. (2018). Penerapan model problem based learning untuk meningkatkan kemampuan critical thinking mahasiswa. Jurnal Pendidikan (Teori dan Praktik), 3(1), 7-12. http://dx.doi.org/10.26740/jp.v3n1.p7-12

Shtulman, A., \& Valcarel, J. (2012). Scientific knowledge suppresses but does not supplant earlier intuitions. Cognition, 124(2012), 209-215. doi: 10.1016/j.cognition.2012.04.005

Taylor, A. K., \& Kowalski, P. (2012). Students' misconceptions in Psychology: How you ask matters ... sometimes. Journal of the Scholarship of Teaching and Learning, 12(3), 62-77.

Taylor, A. K., \& Kowalski, P. (2014). Student misconceptions: Where do they come from and what can we do? In V. A. Benassi, C. E. Overson, \& C. M. Hakala (Eds.), Applying science of learning in education: Infusing psychological science into the curriculum (pp. 259-273). Society for the Teaching of Psychology.

Uribe-Enciso, O. L., Uribe-Enciso, D. S. U., \& Daza, M. D. P. V. (2017). Critical thinking and its importance in education: Some reflections. Rastros Rostros, 19(34), 78-88. https://doi.org/10.16925/ra.v19i34.2144

Verburgh, A., François, S., Elen, J., \& Janssen, R. (2013). The assessment of critical thinking critically assessed in higher education: A validation study of the CCTT and the HCTA. Education Research International, 2013, 1-14. http://dx.doi.org/10.1155/2013/198920

Vosniadou, S. (2019) The development of students' understanding of science. Frontiers in Education, 4(32), 1-6. https://doi.org/10.3389/feduc.2019.00032 
Wilson, J. A. (2018). Reducing pseudoscientific and paranormal beliefs in university students through a course in science and critical thinking. Science \& Education, 27(1), 183-210. https://doi.org/10.1007/s11191-0189956-0

Winenggar, R. P., \& Hastjarjo, T. D. (2015) Pengaruh metode mind mapping terhadap critical thinking [Unpublished undergraduate's thesis]. Faculty of Psychology, Universitas Gadjah Mada.

Zajac, R., Garry, M., London, K., GoodyearSmith, F., \& Hayne, H. (2013). Misconceptions about childhood sexual abuse and child witnesses: Implications for psychological experts in the courtroom. Memory, 21(5), 608-617. http://dx.doi.org/10.1080/09658211.2013 .778287 